Рекомендована д. фрармац. наук, профр. Т. А. Грошовим

УДК 615.1:378.147:378.091.2(477:4)

DOI 10.11603/2312-0967.2017.4.8339

\title{
ПОРІВНЯЛЬНИЙ АНАЛІЗ ПРОФЕСІЙНОЇ ПІДГОТОВКИ СТУДЕНТІВ І КУРСУ СПЕЦІАЛЬНОСТІ «ФАРМАЦІЯ» В УКРАЇНІ ТА НІМЕЧЧИНІ
}

\author{
() О. М. Горошко ${ }^{1}$, О. М. Коровенкова ${ }^{1}$, А. О. Паламар ${ }^{1}$, Н. С. Богдан ${ }^{1}$, \\ О. О. Ровінськийㅁ, В. Г. Зеленюк ${ }^{1}$, О. С. Шпичак ${ }^{2}$
}

Вищий державний навчальний заклад України «Буковинський державний медичний університет», Чернівці Національний фрармацевтичний університет², Харків

shpychak.oleg@gmail.com

\begin{abstract}
Мета роботи. Вивчення процесу ознайомлення студентів I курсу фрармацевтичних фракультетів 3 майбутньою спеціальністю у вищому навчальному закладі (ВН3) порівняно 3 аналогічним курсом Боннського університету (Німеччина).

Матеріали і методи. Використано нормативно-правову базу, що регулює освітній процес в Україні та Німеччині: проведено аналіз організації підготовки студентів фрармацевтичних фракультетів. Для порівняльного аналізу обрано фрармацевтичний фракультет Боннського університету (Німеччина).

Результати й обговорення. Встановлено, що відмінності у дисциплінах, які дають можливість ознайомити студентів-магістрів із майбутньою спеціальністю, $€$ незначними, а саме більше теоретичного матеріалу, що можна пояснити відносно молодим періодом становлення фрармації в Україні. Перевагою у підготовці вітчизняних студентів є проходження практичної підготовки на базі навчально-виробничої аптеки, що сприяє адаптації майбутніх випускників на робочому місці.

Висновки. Дисципліна «Вступ у фрармацію» забезпечує ознайомлення першокурсників фрармацевтичних факультетів з особливостями фрармацевтичної справи аналогічно як і в європейському університеті м. Бонн (Німеччина) під час вивчення курсу «Arzneimittelformenlehre».
\end{abstract}

Ключові слова: фрармацевтичні кадри; якість освіти; вступ у фрармацію.

Вступ. Український фрармацевтичний ринок в останні роки демонструє високі темпи росту і характеризується жорсткою конкуренцією між вітчизняними та іноземними виробниками лікарських засобів і виробів медичного призначення. Розвиток фрармацевтичного сектора в Україні характеризується збільшенням частки наукоємної, високотехнологічної продукції, що відповідає міжнародним стандартам, яких дотримуються найвідоміші світові лідери фрармацевтичної індустрії $[1,2]$. Організація та фрункціонування відповідної системи якості й належне виробництво лікарських засобів залежать від підготовки, починаючи 3 першого курсу, кваліфікованих фрахівців, тому $€$ важливим аналіз підготовки кадрів, оскільки для розвитку галузі необхідна достатня кількість кваліфрікованого персоналу [3, 4].

Підвищення якості освіти майбутніх фрахівців є передумовою інтеграції вищої медичної та фрармацевтичної освіти до європейського освітнього та наукового простору $[5,6,7]$. Проте запровадження кращих практик у цій галузі передбачає вивченню досвіду вищих медичних навчальних закладів за останні десять років, вивченню яких присвячені роботи вітчизняних науковців, зокрема: питанням становлення фрармації та підготовки фрармацевтичних кадрів в Україні (В. П. Чер-них, А. А. Котвіцька, В. А. Георгіянц, Ю. П. Спіженко, І. С. Вітенко, О. П. Волосовець та ін.), проведенню порівняльного аналізу з провідними закордонними навчальними закладами (Л. Вишневська, Т. Загірна, Т. Слінчук, І. Алєксєєва та ін..), фрормуванню компетентностей майбутніх фрахівців фрармацевтичного профрілю у вищих навчальних закладах (Н. Альохіна, Л.Галій, Г. Глембоцька, В. Голубцов, Н. Денисова, І. Комісінська, Л. Пляка, О. Тутутченко та ін.), особливостям практичної підготовки спеціалістів та діагностиці якості рівня підготовки (О. Геруш, О. Алексюк, С. Архангельський, В. Галузінський, П. Гальперін, В. Пікельна, І. Підласий, А. Савельєв, Н. Тализіна, Т. Козлов, О. Тєлєжкін та ін.). Разом із профресійною підготовкою фрахівців фрармацевтичної галузі України розвивається й фрармацевтична наука та промисловість. Також важлива роль відводиться дослідженням із фрармакогнозії, технології лікарських фрорм, фрармацевтичної хімії, освоєнню виробництва високоефективних лікарських засобів (В. Черних, С. Штриголь, І. Заморський, О. Геруш, О. Горошко, А. Паламар та ін.).

ISSN 2312-0967. Pharmaceutical review. 2017. № 4 
Однією з найважливіших ланок у підготовці спеціалістів є додипломне навчання, оскільки вже з першого курсу формується не тільки студент ВНЗ, але і спеціаліст відповідного напрямку [8].

Мета роботи - вивчення процесу ознайомлення 3 фармацевтичною спеціальністю студентів початкових курсів у Вищому державному навчальному закладі України «Буковинський державний медичний університет» (БДМУ) - фрармацевтичному фракультеті порівняно $з$ аналогічним курсом Боннського університету (Німеччина).

Матеріали і методи. Нормативно-правова база, що регулює освітній процес в Україні та Німеччині, організація підготовки студентів фрармацевтичних фракультетів. Для порівняльного аналізу обрано фрармацевтичний фракультет Боннського університету (Рейнський університет Фрідріха Вільгельма в Бонні, нім. Rheinische Friedrich-Wilhelms-Universität Bonn) один 3 найбільших і найвідоміших університетів Німеччини, зважаючи на зацікавленість усіх, як керівників освіти, так і споживачів освітніх послуг, тих, хто навчається та навчає - студентів та батьків.

Навчальний план для студентів першого курсу Вищого державного навчального закладу України «Буковинський державний медичний університет», окрім 15 дисциплін, передбачає вивчення дисципліни «Вступ у фармацію» (табл. 1). Всього згідно з робочою навчальною програмою передбачено 60 год, 3 яких 20 год відведено на лекційні заняття, 20 на практичні і 20 на семінарські заняття. Навчальна дисципліна «Вступ у фрармацію» належить до циклу дисциплін професійно-орієнтованої підготовки фрахівців спеціальності «Фармація».
Відповідно до вимог галузевого стандарту вищої освіти $[9,10]$ навчальна дисципліна «Вступ у фрармацію» виконує роль зв'язувальної ланки між теоретичними дисциплінами, які фрормують профріль провізора та закладає основи вивчення студентами аптечної технології лікарських засобів, промислової технології лікарських засобів, організації та економіки у фрармації, технології лікувальних косметичних засобів, біофрармації, належної фрармацевтичної практики і призначена для покращення професійної і теоретичної підготовки спеціалістів вищої кваліфрікації в галузі фрармації. Дана дисципліна дає можливість студенту усвідомити сутність обраної професії, практично презентувати майбутню спеціальність і в подальшому свідомо підходити до подальшого навчання. Під час лекційних та семінарських занять студенти першого року навчання мають можливість ознайомитися 3 історією фрармації та її основоположниками, лікознавства на різних етапах розвитку суспільства, основними етапами становлення та розвитку фармацевтичної науки і практики в Україні, сучасними напрямками розвитку фрармацевтичної галузі та професійною діяльністю в Україні й за кордоном.

Семінарські заняття проходять у вигляді співбесіди, круглих столів та передбачають виконання тематичних робіт та їх захист у вигляді презентацій. Кращі роботи можуть мати продовження у виступах авторів на студентських наукових гуртках.

Практичні заняття об'єднають початкові знання із двох професійно-орієнтовних дисциплін: організація та економіка фрармації та аптечна технологія лікарських засобів. У заняття, які передбачають знання 3 організації та економіки фрармації, закладено основні

Таблиця 1. Обсяг аудиторних годин для студентів першого курсу фармацевтичного фракультету вищого державного навчального закладу України «Буковинський державний медичний університет»

\begin{tabular}{|c|c|c|c|c|}
\hline \multirow{2}{*}{$\begin{array}{l}\text { № } \\
\text { 3/ח }\end{array}$} & \multirow{2}{*}{$\begin{array}{c}\text { Назва } \\
\text { дисципліни }\end{array}$} & \multicolumn{3}{|c|}{ Кількість годин } \\
\hline & & лекційних & семінарських & практичних \\
\hline 1 & Іноземна мова & - & - & 50 \\
\hline 2 & Українська мова & - & - & 30 \\
\hline 3 & Історія України та української культури & 20 & 10 & - \\
\hline 4 & Латинська мова & - & - & 60 \\
\hline 5 & Філософія & 20 & - & 20 \\
\hline 6 & Біологія з основами генетики & 20 & - & 50 \\
\hline 7 & Біологічна фрізика з фрізичними методами аналізу & 20 & - & 60 \\
\hline 8 & Вища математика і статистика & 20 & - & 50 \\
\hline 9 & Анатомія та фрізіологія людини & 30 & - & 70 \\
\hline 10 & Етика і деонтологія у фрармації & 10 & 30 & - \\
\hline 11 & Загальна та неорганічна хімія & 30 & - & 80 \\
\hline 12 & Безпека життєдіяльності & 24 & - & 16 \\
\hline 13 & Курс на вибір студента & 40 & 80 & - \\
\hline 14 & Фізичне виховання & - & - & 30 \\
\hline 15 & Вступ у фармацію & 20 & 20 & 20 \\
\hline
\end{tabular}

ISSN 2312-0967. Фармацевтичний часопис. 2017. № 4 
знання загальних вимог до організації фрармацевтичного забезпечення населення, організації роботи аптеки як закладу охорони здоров'я, організації забезпечення лікарськими засобами та іншими товарами аптечного асортименту, вивчають основні нормативні документи, що регламентують діяльність в галузі срармації. У практичні заняття з технології ліків закладено основи знань студентами загальних вимог до виробничої діяльності аптеки та є сполучною ланкою між теоретичними дисциплінами, що формують профріль магістра фрармації. Велику увагу приділяють вивченню принципів дозування, зважування та пакування лікарських фрорм, що є основою при вивченні професійно-орієнтованої дисципліни «Аптечна технологія лікарських засобів».

Основні практичні заняття проводяться на базі навчально-виробничої аптеки, яка функціонує на базі БДМУ. Це допомагає студентам оволодіти сучасними методами та срормами організації аптечної справи, формуванню в студентів, на базі одержаних у вищому навчальному закладі знань, професійних умінь і навичок для прийняття самостійних рішень під час їх майбутньої профресійної роботи в реальних ринкових і виробничих умовах, виховання потреби систематично набувати нові знання та творчо їх застосовувати у практичній діяльності. На базі аптеки студенти можуть побачити не тільки «зародження» лікарської форми, але і повний її «життєвий цикл», тобто, від підготовчого етапу, приготування, срасування, офрормлення до відпуску та власне до реалізації.

Зручне розміщення аптеки дозволяє повноцінно відпрацьовувати практичні навики. Для повного забезпечення відпрацювань, передбачених програмою практики практичних навиків, $є$ можливість доповнити матеріалами бази кафедри, оскільки відтворити практичну діяльність провізора в рамках кафедри повністю досить складно. На практичному занятті студенти повинні засвоїти та скласти передбачені програмою практичні навички, які заносяться у протокол.

Окрім навчально-методичного оснащення кабінету кафредри фрармації та навчально-виробничої аптеки, на допомогу студентам $€$ сервер дистанційного навчання, на якому студенти можуть знайти всю необхідну інфрормацію для самостійної підготовки до практичного заняття. Завершується вивчення дисципліни складанням підсумкового модульного контролю, який передбачає теоретичні питання, що охоплюють матеріали лекцій, семінарських занять та виконання основних практичних навиків, які освоїли на практичних заняттях.

Організація навчального процесу в Боннському університеті Німеччини майже така, як і в фрармацевтичних університетах України (табл. 2) [11].

Таблиця 2. Обсяг аудиторних годин для студентів першого курсу Боннського університету фармацевтичного факультету

\begin{tabular}{|c|c|c|c|c|}
\hline \multirow{2}{*}{$\begin{array}{l}\text { № } \\
\text { 3/ח }\end{array}$} & \multirow{2}{*}{ Назва дисципліни } & \multicolumn{3}{|c|}{ Кількість годин } \\
\hline & & лекційних & семінарських & практичних \\
\hline 1 & 2 & 3 & 4 & 5 \\
\hline 1 & $\begin{array}{l}\text { Квалітативний аналіз із неорганічної } \\
\text { xiмiї Einführung in die qualitative Analyse } \\
\text { anorganischer Arznei-, Hilfs- und } \\
\text { Schadstoffe (1. Sem.) }\end{array}$ & $\begin{array}{c}39 \\
\text { (перше півріччя) }\end{array}$ & 27 & 112 \\
\hline 2 & $\begin{array}{l}\text { Основи технології виробництва ліків } \\
\text { Grundlagen der Arzneiformenlehre }\end{array}$ & 19,5 & $\begin{array}{c}10 \\
\text { (семінар із } \\
\text { термінології як } \\
\text { частина предмета) }\end{array}$ & $\begin{array}{c}75 \\
\text { (блок практичних } \\
\text { занять) }\end{array}$ \\
\hline 3 & $\begin{array}{l}\text { Систематика рослин (за морфологією } \\
\text { та анатомією) Pflanzenmorphologie und } \\
\text {-anatomie }\end{array}$ & 25,25 & (практичні заняття & 3 та 4 відповідно) \\
\hline 4 & $\begin{array}{l}\text { Основи фізики } \\
\text { Physik für Mediziner und Pharmazeuten }\end{array}$ & 58,5 & & $\begin{array}{c}33 \\
\text { (в другому } \\
\text { півріччі) }\end{array}$ \\
\hline 5 & $\begin{array}{l}\text { Основи мат. аналізу. } \\
\text { Mathematik und statistische Methoden für } \\
\text { Pharmazeuten }\end{array}$ & 19,5 (перевірка зн & $\begin{array}{l}\text { lь відбувається за дс } \\
\text { омашнього завдання }\end{array}$ & могою вирішення \\
\hline 6 & $\begin{array}{l}\text { Основи аналітичної хімії } \\
\text { Einführung in die quantitative Analyse } \\
\text { anorganischer Arznei-, Hilfs- und } \\
\text { Schadstoffe (2. Sem.) }\end{array}$ & $\begin{array}{c}39 \\
\text { (друге півріччя) }\end{array}$ & 10,5 & 120 \\
\hline 7 & $\begin{array}{l}\text { Основи органічної хімії } \\
\text { Grundlagen der organischen Chemie } \\
\text { (2. Sem.) }\end{array}$ & $\begin{array}{c}19,5 \\
\text { (друге півріччя) }\end{array}$ & $\begin{array}{c}19,5 \\
\text { (друге півріччя } \\
\text { семінар із } \\
\text { номенклатури) }\end{array}$ & $\begin{array}{c}\text { у першому } \\
\text { півріччі другого } \\
\text { курсу }\end{array}$ \\
\hline
\end{tabular}

ISSN 2312-0967. Pharmaceutical review. 2017. № 4 
Фармацевтична освіта

Pharmaceutical education

Продовження табл. 2

\begin{tabular}{|c|l|c|c|c|}
\hline 1 & \multicolumn{1}{|c|}{2} & 3 & 4 & - \\
\hline 8 & $\begin{array}{l}\text { Анатомія людини } \\
\text { Grundzüge der Anatomie für } \\
\text { Pharmazeuten }\end{array}$ & 26 & - \\
\hline 9 & $\begin{array}{l}\text { Фізіологія людини } \\
\text { Physiologie und Pathophysiologie für } \\
\text { Pharmazeuten }\end{array}$ & 29,25 & (7 семінарських занять) \\
\hline 10 & $\begin{array}{l}\text { Miкробіoлогія } \\
\text { Einführung in die Medizinische } \\
\text { Mikrobiologie, Hygiene und }\end{array}$ & 19,5 & \multicolumn{1}{|c|}{35} \\
\hline
\end{tabular}

Кваліфрікаційні вимоги до персоналу регламентуються «Федеральним аптечним порядком» та «Порядком допуску до практики» [12].

Результати й обговорення. Слід зазначити, що у студентів-фрармацевтів Боннського університету вступною дисципліною $€$ «Arzneimittelformenlehre» (наука про лікарські фооми), яку вивчають один раз на тиждень впродовж 2 місяців. При цьому навчальні плани першого курсу передбачають проходження практики з даної дисципліни. Предмет передбачає 10 лекційних занять та семінарські заняття тривалістю 4-5 год на день (2 тижні), під час яких студенти відпрацьовують практичні навики.

Практичні заняття (семінари) проводяться на базі кафедри у відповідних лабораторіях, які оснащені всім необхідним для виконання лабораторної роботи. Під час практичного заняття студенти повинні освоїти не тільки основні навики дозування та фрасування (як передбачено програмою зі Вступу), але й виготовляти основні лікарські фрорми, які можуть відпускатися на базі аптеки, як екстемпоральний лікарський засіб: порошки, розчини, мазі, гелі, креми, супозиторії та чаї. Оскільки ін'єкційні лікарські фрорми не виготовляють в аптеці, тому їх не включають у програму даної практики. Виконання лабораторної роботи передбачає оформлення протоколу. Завершується дисципліна складанням іспиту (критерій оцінювання «зараховано» чи «незараховано») і передбачає перевірку правильності приготування лікарської фрорми.

Отже, відмінності у дисциплінах, які дають можливість ознайомити студентів-магістрів 3 майбутньою спеціальністю, незначні, а саме «Вступ у фрармацію» містить більше теоретичного матеріалу, який включає історію фрармації, а також передбачає вивчення законодавчої бази, що можна пояснити відносно молодим періодом становлення фармації в Україні. Вітчизняна фармацевтична індустрія сьогодні на стадії розвитку, враховуючи історично складені передумови. Тому нормативна база часто переглядається і поновлюється, що пояснюється необхідністю включення тем, які охоплюють вивчення законодавчих документів починаючи з першого курсу.

Перевагою у підготовці студентів при вивченні дисципліни «Вступ у фрармацію» можна вважати проходження практичної підготовки на базі навчально-виробничої аптеки, що дозволяє у майбутньому зменшити час соціальної, психологічної, професійної адаптації випускників на робочому місці, ссрормувати цілісну картину майбутньої діяльності, оцінити рівень теоретичної підготовки, необхідної для виконання роботи, отримати навички самостійного виконання роботи, зрозуміти соціально-етичну направленість професії.

Висновки. Отже, встановлено, що «Вступ у фрармацію» $є$ навчальною дисципліною, яка забезпечує необхідну підготовку студентів до вивчення професійно-орієнтованих дисциплін та мотивує їх до майбутньої діяльності. Разом з тим, незважаючи на різницю в назві предмета та деякі відмінності в організації навчального процесу першокурсники мають можливість ознайомитися 3 особливостями фармацевтичної справи починаючи з I курсу аналогічно, як і студенти європейського фрармацевтичного вузу м. Бонн (Німеччина).

Перспективи подальших досліджень. Одним із системних завдань, що вимагають напруженої роботи всіх колективів вищих медичних (фрармацевтичного) навчальних закладів, $€$ приведення навчальних планів та програм до- та післядипломної підготовки магістрів фрармації відповідно до європейської практики, оскільки відсутній їх глибокий комплексний аналіз та не визначені тенденції їх подальшого ресормування у контексті максимального наближення до потреб практичної охорони здоров'я з урахуванням євроінтеграційних змін у розвитку галузі та країни загалом.

ISSN 2312-0967. Фармацевтичний часопис. 2017. № 4 


\title{
СОПОСТАВЛЕНИЕ СОВРЕМЕННЫХ ТЕНДЕНЦИЙ ПОДГОТОВКИ ФАРМАЦЕВТИЧЕСКИХ КАДРОВ В УКРАИНЕ И ГЕРМАНИИ
}

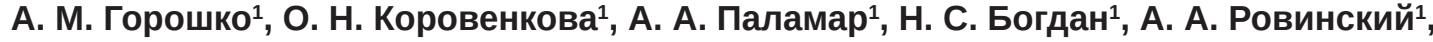 \\ В. Г. Зеленюк ${ }^{1}$, О. С. Шпичак ${ }^{2}$
}

Высшее государственное учебное заведение Украины «Буковинский государственный медицинский университет» ${ }^{1}$, Черновцы Национальный фрармацевтический университет², Харьков

shpychak.oleg@gmail.com

\begin{abstract}
Цель работы. Изучение процесса ознакомления студентов начальных курсов фрармацевтических фракультетов с будущей специальностью в высшем учебном заведении (ВУЗе) по сравнению с аналогичным курсом Боннского университета (Германия).

Материалы и методы. Использована нормативно-правовая база, регулирующая образовательный процесс в Украине и Германии; проведен анализ организации подготовки студентов фрармацевтических фракультетов. Для сравнительного анализа был избран фрармацевтический фракультет Боннского университета (Германия).

Результаты и обсуждение. Установлено, что различия в дисциплинах, которые дают возможность ознакомить студентов-магистров с будущей специальностью, незначительны, а именно в преобладании теоретического материала, что можно объяснить относительно молодым периодом становления фрармации в Украине. Преимуществом в подготовке отечественных студентов является прохождение практической подготовки на базе учебно-производственной аптеки, что способствует адаптации выпускников на рабочем месте.

Выводы. Дисциплина «Введение в фрармацию» обеспечивает ознакомление первокурсников фрармацевтических факультетов Украины с особенностями фрармацевтического дела аналогично, как и в европейском университете г. Бонн (Германия) при изучении курса «Arzneimittelformenlehre».
\end{abstract}

Ключевые слова: фрармацевтические кадры; качество образования; вступление в фрармацию.

\section{COMPARATIVE ANALYSIS OF THE FIRST-YEAR PHARMACY STUDENTS' TRAINING IN UKRAINE AND GERMANY}

O. M. Goroshko ${ }^{1}$, O. M. Korovenkova ${ }^{1}$, A. O. Palamar ${ }^{1}$, N. S. Bogdan ${ }^{1}$, O. O. Rovinskyi ${ }^{1}$, V. H. Zeleniuk ${ }^{1}$, O. S. Shpychak ${ }^{2}$

Bukovina State Medical University ${ }^{1}$, Chernivtsi

National University of Pharmacy², Kharkiv

shpychak.oleg@gmail.com

The aim of the work. Studying the familiarization process of the first-year pharmacy students with their future specialty at Ukrainian higher educational institution in comparison with similar study course at the University of Bonn (Germany).

Materials and Methods. Regulatory framework that regulates educational process in Ukraine and Germany and analysis of the students' training organization at pharmaceutical departments. The Pharmaceutical Faculty at University of Bonn (Germany) was chosen for comparative analysis.

Results. It has been found that differences in disciplines, which provide a possibility to make Master Degree students acquaint with their future specialty, are insignificant with the main distinction in the prevalence of theoretical material, which can be explained by relatively early period of the establishment of pharmacy in Ukraine. However, the advantage in the Ukrainian students' training is a practical training at an educational-compounding pharmacy, which contributes to the adaptation of upcoming graduates at the workplace.

Conclusions. The course "Introduction to Pharmacy" provides the familiarization of the first year students of the pharmaceutical universities of Ukraine with special aspects of pharmacy and is similar to the course «Arzneimittelformenlehre» in the European University of Bonn (Germany).

Key words: pharmaceutical personnel; quality of education; introduction to pharmacy.

ISSN 2312-0967. Pharmaceutical review. 2017. № 4 
Фармацевтична освіта

Pharmaceutical education

\section{Список літератури}

1. Шабельник Т. Сучасний стан фрармацевтичного ринку України / Т. Шабельник // Інституціональна економіка. 2013. - № 6. - С. 40-42.

2. Литвиненко Л. Л. Перспективи розвитку фрармацевтичного ринку України в умовах поглиблення процесів євроінтеграції / Л. Л. Литвиненко, А. О. Собкова // Проблеми підвищення ефективності інфрраструктури. 2015. - С. 51-57.

3. Зайченко А. Ю. Интерпретация требований стандарта ISO 9001:2008 относительно управления человеческими ресурсами / А. Ю. Зайченко, С.В.Русанова // Фармація України. Погляд у майбутнє: VII Нац. з'їзд фрармацевтів Украни, 15-17 верес. 2010 р., Харків. У 2 т. : [матеріали]. - Х. : НФаУ, 2010. - Т. 2. - С. 413.

4. Підготовка фрармацевтичних кадрів в Україні [Електронний ресурс] - Режим доступу до ресурсу: pidruchniki. com /1342012037523/ pidgotovka_ farmatsevtichnih_ kadriv ukrayini.

5. Зарічна Т. П. Порівняльний аналіз систем фрармацевтичної освіти в Україні та деяких країнах світу / Т. П. Зарічна // Актуальні питання фрармацевтичної і медичної науки та практики. - 2015. - № 2. - С. 106-109.

6. Сліпчук В. Л. Прогностичні напрями професійної підготовки фрахівців фрармацевтичної галузі України в умовах євроінтеграції https [Електронний ресурс] / В. Л. Сліпчук - Режим доступу до ресурсу: www.narodnaosvita.kiev.ua 7. Формування правової обізнаності як компонента про-

\section{References}

1. Shabelnyk T. The current state of the pharmaceutical market of Ukraine. Instytutsionalna ekonomika ekonomist. 2013;6: 40-42. Ukrainian.

2. Lytvynenko LL, Sobkova AO. Prospects of development of the pharmaceutical market of Ukraine in conditions of deepening of European integration processes Problemy pidvyshchennia efektyvnosti infrastruktury. 2015; 51-57. Ukrainian.

3. Zaychenko AYu, Rusanova SV. Interpretation of the requirements of the ISO 9001: 2008 Standard on Human Resources Management Farmatsiia Ukrainy. Pohliad u maibutnie: VII Nats. zizd farmatsevtiv F 24 Ukrainy, 15-17 veres. 2010 r., Kharkiv. U 2 t.: [materialy]. Kh.: NFaU. 2010; 2: 413. Ukrainian.

4. Preparation of pharmaceutical personnel in Ukraine [Electronic resource] - Available at: pidruchniki.com / 1342012037523 / pidgotovka_farmatsevtichnih_kadriv_ ukrayini. Ukrainian

5. Zarichna TP. Comparative analysis of pharmaceutical education systems in Ukraine and some countries of the world. Aktualni pytannia farmatsevtychnoi i medychnoi nauky ta praktyky. 2015;2: 106-9. Ukrainian.

6. Slipchuk VL. Prognostic directions of professional training of specialists of the pharmaceutical industry of Ukraine in the context of the European integration of https [Electronic resource]. Available at: www.narodnaosvita. kiev.ua. Ukrainian. фресійної компетентності фрармацевтичних працівників у країнах Європейського Союзу (досвід Чеської Республіки) / І. М. Алєксєєва, М. С. Пономаренко, О. Г. Алексєєв [та ін.] // Актуальные вопросы фрармацевтической и медицинской науки и практики. - 2016. - № 2 (21). - С. 96101.

8. Гаврилова Н. Б. Особливості організації та вдосконалення системи навчання в умовах Болонського процесу / Н. Б. Гаврилова, В. В. Гузєва // Фармація України. Погляд у майбутнє : зб. наук. пр. - Харків, 2010. - Т. 2. С. 198-200.

9. Про вищу освіту : Закон України від 01.07.2014 № 1556-VII. Розділ XV. Пункт 7. «Прикінцеві та перехідні положення» [Електронний ресурс]. - Режим доступу: http://zakon2.rada.gov.ua/laws/show/1556-18/page.

10. Галузевий стандарт вищої освіти [Електронний ресурс] - Режим доступу до ресурсу: http://testcentr.org.ua 11. Regulating pharmaceuticals in Europe: striving for efficiency, equity and quality / [Edited by Mossialos Elias, Mrazek Monique, Walley Tom]. - Open University Press, 2004. - 394 р. - ISBN 0-335-21465-7. - Режим доступу: http://www.euro.who.int/document/E83015.pdf

12. Gesetz über den Beruf des pharmazeutisch-technischen Assistenten/ Ein Service des Bundesministeriums der Justiz in Zusammenarbeit mit der juris $\mathrm{GmbH}$ - Режим доступу: http://www.apothekerkammer-niedersachsen.de/ ausbildung-_pta.php

7. Alyeksieieva IM, Ponomarenko MS, Aleksieiev $\mathrm{OH}$. [Formation of legal awareness as a component of the professional competence of pharmaceutical workers in the countries of the European Union (experience of the Czech Republic)]. Aktualnye voprosy farmatsevticheskoy i meditsinskoy nauky i praktiky. 2016;2(21): 96-101. Ukrainian.

8. Havrylova NB, Huzieva VV. [Features of the organization and improvement of the education system in the Bologna process] Farmatsiia Ukrainy. Pohliad u maibutnie: zb. nauk. pr. Kharkiv. 2010;2: 198-200. Ukrainian.

9. The Law of Ukraine «On Higher Education» of 01.07.2014 № 1556-VII. Section XV Item 7. "Final and Transitional Provisions" [Electronic resource]. Available at: http://zakon2. rada.gov.ua/laws/show/1556-18/page.

10. Branch standard for higher education [Electronic resource]. Available at: http://testcentr.org.ua

11. Regulating pharmaceuticals in Europe: striving for efficiency, equity and quality / [Edited by Mossialos Elias, Mrazek Monique, Walley Tom]. - Open University Press, 2004. - 394 p. - ISBN 0-335-21465-7. - Available at: http:// www.euro.who.int/document/E83015.pdf

12. Gesetz über den Beruf des pharmazeutisch-technischen Assistenten/ Ein Service des Bundesministeriums der Justiz in Zusammenarbeit mit der juris $\mathrm{GmbH}$ - Available at: http://www.apothekerkammer-niedersachsen.de/ausbildung_pta.php 